\title{
Meslekî eğitim merkezinde çıraklık eğitimi gören bireylerin beslenme durumları ve antropometrik açıdan değerlendirilmesi: Van ili örneği
}

Sebile Merve Onur $^{1} \odot$, Seda Karaöz Arıhan ${ }^{2 *}$

' M.A., Doktora Öğrencisi | Ankara Üniversitesi, Sosyal Bilimler Enstitüsü, Fizik Antropoloji Anabilim Dalı, Ankara / TÜRKiYE 2 Dr. Öğr. Üyesi | Van Yüzüncü Yıl Üniversitesi, Edebiyat Fakültesi, Antropoloji Bölümü, Van / TÜRKiYE

\section{Öz}

Bu çalışma Van ilinde bulunan Vali Ali Paşa Mesleki Teknik Eğitim Merkezi'nde çıraklık eğitimi gören bireylerin beslenme alışkanlıklarını saptamak, vücut kompozisyonunu belirlemek, literatürde bulunan mevcut referans değerler ile karşılaştırmak ve bireylerin fiziki yapısını antropometrik yöntemlerle değerlendirerek vücut bileşimini ortaya koymak amacıyla yapılmıştır. Çalışma kapsamında 261 erkek 117 kadın olmak üzere toplamda 378 birey katılmıştır. Bireylerden boy uzunluğu, vücut ağırllğı, bel çevresi ve kalça çevresi ölçümleri alınmıştır. Aynı zamanda bireylerin beslenme alıskanlıklarının incelenmesi amacıyla düzenli öğün tüketme sıklıkları incelenip tablolar halinde sunulmuştur. Araștırma bulgularına göre erkek bireylerin boy uzunluk ortalaması 169,69 $\mathrm{cm}$, ağırlık ortalaması $64,02 \mathrm{~kg}$, beden kütle endeksi (BKE) ortalaması $22,14 \mathrm{~kg} / \mathrm{m}^{2}$ dir. Kadın bireylerde boy uzunluk ortalamas1 158,68 $\mathrm{cm}$, ağırlık ortalaması $57,31 \mathrm{~kg}$, BKE ortalaması $22,83 \mathrm{~kg} / \mathrm{m}^{2}$ olarak tespit edilmiştir. Bireylerin en fazla atladıkları öğünün sabah kahvaltısı olduğu saptanmıştır. Sağlığın korunması ve geliştirilmesi için beslenme durumunun toplumu olușturan bireyler üzerinde sürekli izlenmesi ve değerlendirilmesi, ileride ortaya çıkabilecek çeşitli hastalıkların önüne geçilmesi bakımından büyük önem taşımaktadır.

Anahtar Sözcükler: Beslenme, antropometri, beden kütle endeksi, çıraklık eğitimi

\section{Giriş}

Toplumun temel amacı sağlıklı ve üretken olmaktır. Üretim için ise insan gücü gerekmektedir. Bireylerin üretime tam olarak katkı sağlamaları, ancak bedenen, ruhen ve sosyal olarak sağlıklı olmalarına bağlıdır. İşçilerin sağlık durumlarını etkileyen faktörlerin başında beslenme gelmektedir. İşçi bireyler, toplumda risk altındaki grup içerisinde yer aldıkları için beslenmelerine ayrı bir özen göstermeleri gerekmektedir.

İnsan bedeninin çevresel etmenlerden ne denli etkilendiğ

\section{Nutritional and anthropometric assessment of individuals having apprenticeship education in vocational education center: Van example \\ Abstract}

This study was carried out to determine the nutritional habits of individuals undergoing apprenticeship training at the Vali Ali Pașa Vocational Technical Education Center in Van, to determine the body composition, to compare it with the existing reference values in the literature, and to reveal the body composition by evaluating the physical structure of individuals using anthropometric methods. A total of 378 individuals, 261 male and 117 female, were participated in the study. Length, body weight, waist circumference and hip circumference measurements were taken from individuals. At the same time, the frequency of regular meals is examined and presented in tables in order to examine the nutritional habits of individuals. According to the research study findings, the average height of male individuals is $169.69 \mathrm{~cm}$, average weight is 64.02 $\mathrm{kg}$, average of body mass index (BMI) is $22.14 \mathrm{~kg} / \mathrm{m}^{2}$. In women, the average height is $158.68 \mathrm{~cm}$, the average weight is $57.31 \mathrm{~kg}$, the average of BMI is $22.83 \mathrm{~kg} /$ $\mathrm{m}^{2}$. It was determined that the most frequent skipped meal by the individuals was breakfast. For the protection and development of health, continuous monitoring and evaluation of the nutritional status on individuals who make up the society are of great importance in terms of preventing various diseases that may arise in the future.

Key Words: Nutritional status, anthropometry, body mass index, apprenticeship training

sosyoekonomik düzey, beslenme faktörleri, stres, yaşanılan aile birey sayısının büyüklügü gibi faktörlerle şekillenmektedir. Bunu belirlemenin en iyi yolu ise insan bedenini ölçmektir. Bu sayede, bu amaçla yararlanılan antropometri, yani insan bedeninin ölçümü ortaya çıاkıştır (Özener ve Duyar, 2003).

İnsan vücut boyutlarının biçimlenmesinde çevresel faktörlerin de rolünün olması, antropometrik ölçülerin, sosyal ve ekonomik koşulların önemli bir yansıtıcısıdır. Villerme'nin 19. yüzyılın başındaki çalışmalarından beri, yoksul kesime mensup bireylerin daha kisa boylu 
ve düşük ağırlığa sahip oldukları bilinmektedir. Yapılan araştırmalar, sosyal sınıflar arasındaki uçurumun derinleşmesine paralel olarak boyut farklılığının belirginleştiğini, buna karşılık sosyal eşitsizlikler giderildikçe ve sağlık imkanları toplumun alt kesimlerine belli bir seviyede sunulmaya başlandıkça aradaki farklılığın azaldığını ve hatta yok olmaya başladığını ortaya koymuştur. Sosyal sinıflar arasındaki eşitsizliklerin büyük çoğunluğunun giderildiği İsveç ve Norveç gibi ülkelerde antropometrik boyut farkl1lkklarının da azalması bunun en açık kanıtıdır (Tanner, 1990).

Antropometrik ölçümler vasıtasıyla bir toplumun genel sağl1k ve beslenme durumu ortaya konulabilmektedir. Ağırlık, boy, beden kütle indeksi, deri altı yağ tabakası ve çevre ölçümleri kullanılarak bir toplumun beslenme durumu ortaya konulabilmektedir (Himes 1991 akt. Duyar ve Özener, 2003, s. 99).

Toplum içinde bulunan bireylerin sağlıklı ve güçlü olarak yaşamlarını sürdürmesinde, sosyal ve ekonomik yönden gelişmesive refah düzeyinin yükselmesinde yeterli ve dengeli beslenme temel şartlardan birisidir (Soylu, 2006). Beslenme, büyümek, vücut fonksiyonlarının düzenli çalışabilmesi ve bireyin yaşamını sağlıklı ve mutlu bir şekilde devam ettirebilmesi için vücudun gerekli gıdalardan yararlanmasıdır (Kavas, 2003). Yeterli ve dengeli beslenme, büyüme, vücudun yenilenmesi ve düzenli çalışabilmesi için gerekli olan besin öğelerinin yeterli miktarda alınmasıdır (Rakıcıoğlu, 1999). Yeterli ve dengeli beslenmek, zihinsel gelişimde ve iş veriminde oldukça önemlidir. Ayrıca yaşam süresinin yükselmesi, sağllk risklerinin azalmasıyla birlikte tüketicilerde giderek yanlış tüketim yerine doğru ve dengeli bir tüketim anlayışını geliştirmektedir (Dölekoğlu ve Yurdakul, 2004).

Beslenme alışkanlıkları bireylerin bedensel ve zihinsel bakımdan sağlıklarını önemli derecede etkilemesi açısından günümüzde tüm dünya ülkelerinde son derece önemli bir konudur. Bireylerin eğitim, gelir ve beslenme bilgi düzeyi, örf, adet ve gelenekler, ilkim, yaşanılan coğrafya, kent veya kırsal kesimde yaşama faktörleri de beslenme alıșkanlıklarına etki eder ve bu alışkanlıkları yönlendirmektedir (Sürücüoğlu, 1999).

Beslenme, aynı zamanda çalışan bireylerin üretim hızını etkileyen önemli etmenlerin başında gelmektedir. Yetersiz ve dengesiz beslenme işçilerde birçok sorunun temelini oluşturmaktadır (Wodsworth vd., 2003). İşin gerektirdiği enerjiyi sağlayacak besinler alınmadığ takdirde bireyde enerji harcaması kısıtlandığından üretim için gerekli fiziksel güç azalmaktadır. İşçi beslenmesi, işçi sağllğının diğer hizmetleri ile birlikte yeterli ve dengeli beslenmesini sağlayarak, çalışanları fiziksel ve ruhsal yönden en yüksek iyilik düzeyine ulaştırmayı ve işçilere en yüksek çalışma kapasitesini kazandırmayı amaçlamalıdır.
Bu çalıșmada Van ilinde bulunan Vali Ali Paşa Mesleki Teknik Eğitim Merkezi'nde çıraklık eğitimi gören bireylerin beslenme durumları ve antropometrik ölçümleri incelenmiş, bireylerin cinsiyet üzerinde sosyoekonomik düzey gibi çevresel ve iş yaşamına ilişkin özellikleri değerlendirilmiştir. Yapılan bu çalışmanın çırak işçilerinin beslenme ve fiziksel özelliklerine $1 s ̧ 1 \mathrm{k}$ tutacağı ve toplumun bilimsel değerlendirilmesinde katkıda bulunacağı ve ileride yapılacak olan çalışmalarda yararlı olacağı kanısındayız.

\section{Gereç ve yöntem}

Yapılan araştırma kapsamında Van ilinde bulunan Vali Ali Paşa Mesleki Eğitim Merkezi'nde, çeşitli iş kollarında eğitim gören 17-30 yaş arasında olan rastgele seçilen 261 erkek, 117 kadın olmak üzere toplamda 378 birey dâhil edilmiştir.

Araştırmaya katılan bireylerden, boy uzunluğu, vücut ağırlı̆̆1, bel çevresi ve kalça çevresi ölçümleri alınmıştır. Ayrıca bireylerin sosyoekonomik düzeylerinin tespiti amacıyla, eğitim durumu, aile içi birey sayısı, ailede çalışan birey sayısı, aylık gelir durumu, oturulan konut mülkiyeti ve 1sınma düzeyi gibi bilgiler kaydedilmiştir.

Bireylerden alınan antropometrik ölçümlerde; boy ölçüsü için antropometre, ağırlık ölçüsü için 100 g’ye duyarlı dijital tartı, çevre ölçüleri için $1 \mathrm{~mm}$ 'ye duyarlı esneme yapmayan şerit metre kullanılmıştır. Alınan ölçümler 2017 yılında Mayıs ve Ekim aylarında alınmıştır. Ayrıca bireylere daha önce hazırlanmış olan beslenme alışkanlıklarına ilişkin anket formu uygulanmıştır. Alınan antropometrik ölçümler Anthropometric Standardization Reference Manual (ASRM) ve International Biological Programme'ın (IBP) önerdiği teknikler doğrultusunda alınmıştır (Weiner ve Lourie, 1969).

Alınan ölçümlerin SPSS 20.0 paket programında istatistiksel analizleri yapılmış olup, bağımsız t testi ve ANOVA testi uygulanmıștır.

\section{Bulgular}

Bireylerin eğitim durumları, sosyoekonomik yapılarının anlaşılabilmesibakımından oldukça önemlidir. Örneklem grubuna bakıldığında erkek bireylerin $\% 72,8$ gibi büyük bir kısminin ortaokul mezunu olduğu görülmektedir. Kadın bireylere bakıldığında ise yine durum benzer şekilde olup \%69,2'si ortaokul mezunudur. Kadın örneklem grubunda üniversite mezunu olan birey bulunmamaktadır. Erkek bireylerde ise \%0,4'lük bir kısmin üniversite mezunu olduğu görülmektedir.

Örneklem grubundaki bireylerin doğum yerlerine bakıldığında erkek bireylerin \%96,6's1 Van, \%2,3'ü Hakkari, \%0,8’i Muğla ve \%0,4’ü Ankara doğumludur. Kadın bireylerin doğum yerleri ise \%96,6 Van, \%2,6's1 Hakkari, \%0,9’u ise Şırnak olarak tespit edilmiştir. 
Hane içinde yaşayan birey sayısı ile sosyoekonomik durum arasında negatif bir ilişkinin olduğu kabul edilmektedir. Diğer bir ifade ile sosyoekonomik düzey arttıkça ailelerde çocuk sayısında azalma görülmektedir. Bu durum, pek çok toplumda olduğu gibi Türkiye'de de görülmektedir. Hanede birey sayısı arttıkça, sağlık için paylaşılan olanaklar, beslenme imkanları azalmaktadır. $\mathrm{Bu}$ sebeple hanede yaşayan birey sayısı sosyoekonomik yapının göstergelerinden birisi olarak kullanılmaktadır (Duyar ve Özener, 2003).

Çalışma kapsamında bireylerin aile içi birey sayılarına bakıldığında 2 bireyden 18 bireye kadar büyük bir dağ 1 llim göstermektedir. En fazla oran ise \%19,5 ile 6 kişilik aile, \%14,2 ile 5 kişilik aile, \%12,6 ile 7 kişilik aile, \%11,9 ile 8 kişilik aileler oluşturmaktadır.

Aile içerisinde çalışan birey sayısı incelendiğinde ise $\% 49,7$ ile 2, \%20,6 ile 3, \%20,1 ile 1 birey bulunmaktadır.

Yapılan bu araştırma kapsamında sigara kullanım sıklığına bakıldığında erkek bireyler $\% 57,9$ oranında sigara kullanırken kadın bireylerin \% 43,6 oranında sigara tükettikleri saptanmıştır. Grup geneline bakıldığında bireylerin \%53,4’ünün sigara kullandığ1 görülmektedir. Yapılan çalışmalara oranla örneklem grubundaki kadın bireylerin sigara kullanım sıklığının oldukça yüksek olduğu görülmektedir.

Yapmış olduğumuz çalışma sonuçları incelendiğinde bireylerin alkol tüketim siklığ1 erkek bireylerde \%10, kadın bireylerde ise \%0,9 olarak tespit edilmiştir. Grup geneline bakıldığında ise toplamda \%7,1 oranında alkol tüketilmektedir.

Bireylerin çalıştıkları yıl miktarı incelenmiştir. Örneklem grubumuz yaş aralığ1 göz önünde bulundurulduğunda 13 y1ldan 20 yıla kadar uzun yillar çalışmış bireyler bulunmaktadır. Bu bireylerin küçük yaşlardan beri çalışmaya başladıkları sonucu ortaya çıkmaktadır. En fazla çalışılan yıl miktarı ise 5 yil ile \%13,5, 6 yıl ile \%12,1 oranında olduğu görülmektedir.

Çalışmada bireylerin aylık gelir dağılımlarına bakıldığında \%40,5’i 500-1000 TL arasında maaş aldı̆̆1 görülmektedir. Bireylerin \%40,2'sinin ise 1000 1500 TL aylık geliri olduğu tespit edilmiştir. Örneklem grubundaki bireylerin büyük çoğunluğunun asgari ücretten daha düşük bir maaş aldığı görülmektedir.

Bireylerin oturdukları konut mülkiyetiincelendiğinde \%61,4'ünün ev sahibi, \%38,6'sının ise kirada oturduğu saptanmıştır. Isınma türlerine bakıldığında ise bireylerin \%73’ü soba, \%23,3'ü kombi, \%3,7'si ise merkezi sistem ile 1sındığı belirtilmiştir.

Mesleki eğitim merkezinde eğitim gören bireylerin meslek grupları incelendiğinde erkek bireylerin \%49'u otomotiv, \%27,6's1 kuaför, \%12,3’ü elektrik, \%5'i yiyecek ve içecek işletmeciliği, $\% 3,8$ 'i mobilya ve $\% 2,3$ 'ü tekstil bölümünde iş eğitimi görmektedirler. Kadın bireyler incelendiğinde $\% 53$ 'ü kuaför, \%23,9’u tekstil, \%23,1'i ise yiyecek ve içecek işletmeciliği bölümünde iş eğitimi görmektedirler.

Bireylere ait antropometrik ölçüm değerleri Tablo 1'de verilmiştir. Örnekleme ait veriler incelendiğinde bağımsız t testi sonuçlarına göre ağırlık ve boy ölçümü arasinda cinsiyetler arası $p<0,001$ düzeyinde, BKE, bel çevresi ve bel-kalça oranı arasında $p<0,05$ düzeyinde anlamlı istatistiksel farklılık olduğu görülmektedir.

Dünya Sağlık Örgütü'nün (WHO) sınıflandırmasına göre Beden Kütle İndeksi değerleri 18,5 değerinin

Tablo 1. Erkek ve kadın bireylerin antropometrik ölçüm değerleri

\begin{tabular}{cccccccc}
\hline & \multicolumn{3}{c}{ Erkekler } & \multicolumn{5}{c}{ Kadınlar } \\
\hline Ölçümler & $\mathbf{n}$ & ort. & ss. & $\mathbf{n}$ & ort. & ss. & Anlamlılık \\
\hline Ağırlık $(\mathrm{kg})$ & 261 & 64,02 & 8,88 & 117 & 57,31 & 8,96 & $0,000^{* *}$ \\
Boy $(\mathrm{mm})$ & 261 & 1699,69 & 64,6 & 117 & 1583,67 & 54,05 & $0,000^{* *}$ \\
BKE $\left(\mathrm{kg} / \mathrm{m}^{2}\right)$ & 261 & 22,15 & 2,70 & 117 & 22,82 & 3,17 & $0,033^{*}$ \\
Bel çevresi $(\mathrm{mm})$ & 261 & 798,79 & 76,45 & 117 & 776,53 & 94,94 & $0,017^{*}$ \\
Kalça çevresi (mm) & 261 & 928,42 & 57,61 & 117 & 938,68 & 88,08 & 0,179 \\
Bel-kalça oranı & 261 & 0,85 & 0,067 & 117 & 0,82 & 0,1035 & $0,003^{*}$ \\
\hline
\end{tabular}

Tablo 2. Erkek ve kadın bireylerin BKE $\left(\mathrm{kg} / \mathrm{m}^{2}\right)$ değerleri

\begin{tabular}{ccccc}
\hline & \multicolumn{2}{c}{ Erkekler } & \multicolumn{2}{c}{ Kadınlar } \\
\hline Ölçümler & $\mathbf{n}$ & $\mathbf{0}$ & $\mathbf{n}$ & $\mathbf{\%}$ \\
\hline Ağır Düzeyde Zayıf $(<16.0)$ & 1 & 0,4 & 1 & 0,9 \\
Orta Düzeyde Zayıf $(\geq 16.0-<17.0)$ & 1 & 0,4 & 2 & 1,7 \\
Hafif Düzeyde Zayıf $(\geq 17.0-<18.5)$ & 14 & 5,4 & 1 & 0,9 \\
Normal $(\geq 18.5-<24.9)$ & 205 & 78,5 & 88 & 75,2 \\
1. Derece Fazla Kilolu $(\geq 25.0-<29.9)$ & 38 & 14,6 & 22 & 18,8 \\
2. Derece Obezite $(\geq 30.0-<39.9)$ & 2 & 0,8 & 3 & 2,6 \\
3. Derece Ölümcül Obezite $(\geq 40.0)$ & 0 & 0 & 0 & 0 \\
\hline
\end{tabular}


Onur ve Karaöz Arıhan | Antropoloji (40) (2020)

Tablo 3. Erkek ve kadın bireylerin kalça oranı değerleri

\begin{tabular}{|c|c|c|c|c|c|c|c|}
\hline \multicolumn{4}{|c|}{ Erkekler } & \multicolumn{4}{|c|}{ Kadinlar } \\
\hline \multicolumn{2}{|c|}{1,0 ve üzeri } & \multicolumn{2}{|c|}{1,0 alt1 } & \multicolumn{2}{|c|}{0,80 ve üzeri } & \multicolumn{2}{|c|}{0,80 alt1 } \\
\hline $\mathbf{n}$ & $\%$ & n & $\%$ & $\mathbf{n}$ & $\%$ & $\mathrm{n}$ & $\%$ \\
\hline 6 & 2,3 & 255 & 97,7 & 63 & 53,9 & 54 & 46,1 \\
\hline
\end{tabular}

altındaki bireyler zayıf, 18,5 ve 24,9 değerleri arasındaki bireyler normal, 25 ve 29,9 arasindaki bireyler aşırı kilolu, 30 ve 39,9 arasındaki bireyler obez, 40 değerinin üzerindeki bireyler ise morbid obez olarak tanımlanmaktadırlar [World Health Organization (WHO), 1995].

Erkek bireylerin BKE değerleri incelendiğinde $\% 78,5$ inin normal düzeyde olduğu, kadın bireylerde ise \%78,6'sinın 1. derecede fazla kilolu olduğu görülmektedir.

Bel/kalça oranı erkeklerde 1,0, kadınlarda 0,8 üzerine çıkmamalıdır (Pekcan, 2008). Tablo 3'te bireylerin bel-kalça oranı incelendiğinde erkeklerin 1,00 ve üzeri $\%$ 2,3, 1,00 ve alt1 olan bireyler ise $\% 97,7$ 'dir. Kadın bireylerin bel kalça oranı ise 0,80 üzeri \% $\% 3,9$ iken 0,80 altının \%46,1 olduğu görülmektedir. Kadınlarda risk grubu altında olan bireylerin sayısının daha yüksek olduğu görülmektedir. Erkeklerde ise risk grubu altında olan birey sayısı oldukça düşüktür.
Bireylerin beslenme alsşkanlıkları incelendiğinde Tablo 4'te bireylerin düzenli kahvaltı yapma sıklıkları verilmiştir. Tabloya göre "evet" cevabinı veren erkek bireyler \%42,1 iken kadın bireylerde bu oran \%40,2'dir. Düzenli kahvaltı yapmayan ve "hayır" cevabını veren erkek bireyler \%14,6 iken kadın bireylerde \%12,0'dır. Bazen düzenli kahvaltı yaptığını belirten bireylere bakıldığında ise erkeklerde oran \%43,3 iken kadın bireylerde $\% 47,9$ olduğu gözlemlenmiştir.

Tablo 5'te bireylerin düzenli öğle yemeği yeme sıklıklarına bakıldığında "evet" cevabını veren erkek bireylerde oran $\% 72,4$ iken kadin bireylerde bu oran \%42,7'dir. Düzenli öğle yemeği yemeyen ve "hayır" cevabını veren erkek bireyler oran olarak \%3,4 iken kadın bireyler \%8,5'tir. Bazen öğle yemeğini yediğini belirten erkek bireylerde oran \%24,1 iken kadın bireylerde bu oran \% 48,7 'dir.

Tablo 6'da bireylerin düzenli akşam yemeği yeme sıklıkları verilmiştir. Tabloya göre "evet" diyen erkek

Tablo 4. Erkek ve kadın bireylerde düzenli kahvaltı yapma sıklığ1

\begin{tabular}{ccccccc}
\hline & \multicolumn{2}{c}{ Erkekler } & \multicolumn{2}{c}{ Kadınlar } & \multicolumn{2}{c}{ Toplam } \\
\hline Düzenli kahvaltı & $\mathbf{n}$ & $\mathbf{0}$ & $\mathbf{n}$ & $\mathbf{\%}$ & $\mathbf{n}$ & $\mathbf{\%}$ \\
\hline Evet & 110 & 42,1 & 47 & 40,2 & 157 & 41,5 \\
Hayır & 38 & 14,6 & 14 & 12,0 & 52 & 13,8 \\
Bazen & 113 & 43,3 & 56 & 47,9 & 169 & 44,7 \\
Toplam & 261 & 100,0 & 117 & 100,0 & 378 & 100,0 \\
\hline
\end{tabular}

Tablo 5. Erkek ve kadın bireylerde düzenli öğle yemeği yeme sıklığ1

\begin{tabular}{ccccccc}
\hline & \multicolumn{2}{c}{ Erkekler } & \multicolumn{2}{c}{ Kadınlar } & \multicolumn{2}{c}{ Toplam } \\
\hline Düzenli öğle yemeği & $\mathbf{n}$ & $\mathbf{\%}$ & $\mathbf{n}$ & $\mathbf{\%}$ & $\mathbf{n}$ & $\mathbf{\%}$ \\
\hline Evet & 189 & 72,4 & 50 & 42,7 & 239 & 63,2 \\
Hayır & 9 & 3,4 & 10 & 8,5 & 19 & 5,1 \\
Bazen & 63 & 24,1 & 57 & 48,7 & 120 & 31,7 \\
Toplam & 261 & 100,0 & 117 & 100,0 & 378 & 100,0 \\
\hline
\end{tabular}

Tablo 6. Erkek ve kadın bireylerde düzenli akşam yemeği yeme sıklığ1

\begin{tabular}{ccccccc}
\hline & \multicolumn{2}{c}{ Erkekler } & \multicolumn{2}{c}{ Kadınlar } & \multicolumn{2}{c}{ Toplam } \\
\hline Düzenli akşam yemeği & $\mathbf{n}$ & $\mathbf{\%}$ & $\mathbf{n}$ & $\mathbf{\%}$ & $\mathbf{n}$ & $\mathbf{\%}$ \\
\hline Evet & 140 & 53,6 & 65 & 55,6 & 205 & 54,2 \\
Hayır & 22 & 8,4 & 6 & 5,1 & 28 & 7,4 \\
Bazen & 99 & 37,9 & 46 & 39,3 & 145 & 38,4 \\
Toplam & 261 & 100,0 & 117 & 100,0 & 378 & 100,0 \\
\hline
\end{tabular}


bireylerin oranı \%53,6 iken kadın bireylerde bu oran $\% 55,6$ 'dır. Düzenli öğle yemeği yemediğini belirterek "hayır" cevabinı veren erkek bireylerin oranı \%8,4 iken kadın bireylerde \%5,1'dir. Bazen öğle yemeği yediğini belirten erkek bireylerin oranı \%37,9 iken kadın bireylerde bu oran \%39,3'tür.

Bireylerin öğün atlama durumlarına bakıldığında, öğün atladığını belirten erkek bireylerin oranı \%40,2 iken kadın bireylerde bu oran \%60,47'dir. Öğün atlamadığını belirten bireylerde ise bu oran erkeklerde \%13 kadınlarda \%5,1'dir. Bazen öğün atladığını belirten erkek bireyler \%46,7 iken kadın bireyler \%34,2 olduğu saptanmıştır.

Bireylerin en sık atladığı öğünün oranlar1 \%37,3 ile sabah kahvaltısı, \%28 ile öğle yemeği ve \%34,7 ile akşam yemeği olduğu tespit edilmiştir.

Bireylerin öğün atlama nedenlerine bakıldığında; yemeği beğenmiyorum diyen erkek bireylerin oran1 \%3,8 iken kadın bireylerde oran \%0,9'dur. Zaman bulamadığını belirten erkek bireylerin oranı $\% 35,6$ iken kadın bireylerde oran \%29,1'dir. Canı istemediği için öğün atladığını belirten erkek bireylerde oran \%50,6 iken kadın bireylerde \%51,3’tür. Diyet yaptığını ve bu yüzden öğün atladığını belirten erkek bireylerin oranı \%4,2 iken kadın bireylerde bu oran \%12'dir. Ekonomik nedenlerden ögün atlayan erkek bireylerde ise oran $\% 5,7$ kadın bireylerde \%6,9 olduğu saptanmıştır.

Bireylerin antropometrik ölçüm değerleri ile düzenli yemek yeme durumu arasındaki ilişki incelendiğinde, bel çevresi ve bel kalça oranı arasında $p<0,05$ düzeyinde anlamlı bir farklılık olduğu görülmüştür. Diğer antropometrik ölçümlerde ise anlamlı bir farklılık bulunmamıștır.

Ayrıca bireylerin eğitim durumu ile ağırlık ve BKE değerleri arasında $p<0,05$ düzeyinde anlamlı bir farklilık olduğu saptanmıştır.

\section{Tartışma ve sonuç}

Bir bireyin sağlı̆̆1; genetik yapıs1, yaşı, cinsiyeti, beslenme durumu, yaşam tarzı, sosyoekonomik, sosyokültürel ve psikolojik durumu gibi birçok etken ile ilişkilidir. Beslenme durumu, sağlığın temel belirleyicisidir (Baysal, 2011). Yeterli ve dengeli beslenmemek bireylerde malnütrisyon, obezite, kalp ve damar hastalıkları, hipertansiyon ve diyabet gibi çeşitli hastalıklara yakalanma riskini arttırmaktadır (Şanlıer, 2005). Bu sebeple bireylerin beslenme alışkanlıklarının düzenlenmesi, sağlıksız beslenmenin açabileceği olası rahatsızlıkların önlenmesi açısından oldukça önemlidir.

Araştırmaya dâhil olan bireylerin antropometrik değerleri incelenmiş ve literatürde yer alan diğer çalışmalar ile karşılaştırılmıştır. Çalışma sonuçlarına göre erkek bireylerin ortalama boy uzunluk değeri 169,9 \pm $6,4 \mathrm{~cm}$, vücut ağırlığ1 $64,0 \pm 8,8 \mathrm{~kg}$, bel çevresi 798,4 $\pm 76,09 \mathrm{~mm}$, kalça çevresi 928,42 \pm 57,6 mm, kadın bireylerde ise ortalama boy uzunluk değeri 158,3 $\pm 5,4$ cm vücut ağırllğ $157,3 \pm 8,9 \mathrm{~kg}$, bel çevresi 776,53 \pm 94,9 mm, kalça çevresi 938,68 \pm 88,0 mm olarak saptanmıştır.

Türkiye Obezite Araştırma Derneği, Cerrahpaşa Üniversitesi Tıp Fakültesi Endokrin Anabilim Dalı ve Türk Diyabet Derneği tarafindan yapılan ortak araştırmaya göre Türkiye'de kilolu olanların oranı (BKE 25-30 kg/m²) \%30,2 iken Obez (BKE>30 kg/ $\mathrm{m}^{2}$ ) olanların oranı ise $\% 22,4$ olarak tespit edilmiştir. Cinsiyetlere göre şişmanlık oranı ise erkeklerde $\% 24$ ve kadınlarda \%32 olarak bulunmuştur (Newman, 2004).

Yaptığımız çalışmada bireylerin BKE değerlerine bakıldığında erkek bireylerde ortalamanın $22,14 \mathrm{~kg} / \mathrm{m}^{2}$ kadın bireylerde ise ortalamanın $22,83 \mathrm{~kg} / \mathrm{m}^{2}$ olduğu tespit edilmiştir. Araştırmaya dâhil olan bireyler BKE'ne göre sinıflandırıldığında erkek bireylerde \%0,4'ünün (1 kişi) ağır düzeyde zayıf, \%0,4'ünün (1 kişi) orta düzeyde zayıf, $\% 5,4$ 'ünün (14 kişi) hafif düzeyde zayıf, \% 78,5'inin (205 kişi) normal, \%14,6'sının (38 kişi) birinci derece fazla kilolu, \%0,8'inin (2 kişi) ikinci derece obez olduğu saptanmıştır. Kadın bireylerin BKE değerlerine bakıldığında ise \%0,9'unun (1 kişi) ağır düzeyde zayıf, $\% 1,7$ 'sinin (2 kişi) orta düzeyde zayıf, \%0,9'unun (1 kişi) hafif düzeyde zayıf, \%75,2'sinin (88 kişi) normal, \%18,8'inin (22 kişi) birinci derece fazla kilolu, \%2,6'sinın (3 kişi) ikinci derece obez olduğu görülmektedir.

Bel kalça oranı incelendiğinde erkek bireylerin \%2,3 ünün (6 kişi), kadın bireylerde ise \%53,9'unun (63 kişi) risk grubunda olduğu tespit edilmiştir.

Hamraa (2013), mobilya üretiminde çalışan erkek işçiler üzerinde yapmış olduğu çalışmada bireylerin ortalama boy uzunluğunu $173,6 \pm 7,6 \mathrm{~cm}$, ortalama vücut ağırllğını 75,9 \pm 10,7 kg, bel çevresi ölçümü 94,5 $\pm 10,1 \mathrm{~cm}$, kalça çevresi ölçümünü $102,04 \pm 8,3 \mathrm{~cm}$ ve BKE değerini ise $25,2 \pm 3,6 \mathrm{~kg} / \mathrm{m}^{2}$ olarak saptamıştır. Bilge (2009) çalışan bireyler üzerinde yapmış olduğu çalışmada işçilerin ortalama boy uzunluğunu $161 \pm 6,08$ cm, vücut ağırlığını 64,9 $\pm 11,8 \mathrm{~kg}$, bel çevresini 83,5 \pm 9,17 cm, kalça çevresini 101,4 $\pm 8,1 \mathrm{~cm}$ ve BKE'ni, 25,1 $\pm 4,48 \mathrm{~kg} / \mathrm{m}^{2}$ olarak tespit etmiştir.

Maden işçileri üzerinde yapılan bir çalışmada bireylerin antropometrik ölçümlerine bakıldığında boy uzunluğu $170 \pm 6,0 \mathrm{~cm}$, vücut ağırlığ1 ortalaması 73,6 \pm $11,93 \mathrm{~kg}$, bireylerin BKE değerleri $25,5 \pm 3,89 \mathrm{~kg} / \mathrm{m} 2$ olarak tespit edilmiştir. Bireylerin bel ve kalça çevresi ortalamalarına bakıldığında ise bu değerler sırasıyla 87,4 $\pm 9,87 \mathrm{~cm}$ ve $99,4 \pm 6,91 \mathrm{~cm}$ olarak bulunmuştur (Bilici, 2006).

Koca Özer ve Gültekin (2013)'in Ankara ilinde yapmış oldukları çalışmada 18-29 yaş grubu arasındaki erkek bireylerin boy uzunluk ortalamas1 173,43 \pm 4,7 $\mathrm{cm}$, vücut ağılllğg 75,30 $\pm 9,81 \mathrm{~kg}$ ve $\mathrm{BKE}$ ise 25,12 $\pm 2,98 \mathrm{~kg} / \mathrm{m}^{2}$ olarak saptanmıştır. Kadın bireylere 
bakıldığında ise 18-29 yaş grubu arasındaki bireylerin boy uzunluğu ortalamas1 $161,96 \pm 6,97 \mathrm{~cm}$, vücut ağırlı̆̆1 ortalamas1 59,26 $\pm 9,84 \mathrm{~kg}$, BKE ortalamas1 ise $22,86 \pm 3,55 \mathrm{~kg} / \mathrm{m}^{2}$ olarak tespit edilmiştir. Veriler yapmış olduğumuz çalışma ile karşılaştırıldığında her iki cinsiyette de boy uzunluk ve ağırlık ortalamasının daha düşük sonuçlar gösterdiği görülmüştür. BKE değerleri karşılaştırıldığında ise çalışma grubundaki erkek bireylerin BKE değerlerinin daha düşük olduğu kadın bireylerde ise benzer sonuçlar gösterdiği saptanmıştır.

Gültekin ve ekibinin (2009) 18-65 yaş arasında olan Türk erişkinleri üzerinde yapmış oldukları çalışmada erkek bireylerin boy ortalamasi 168,88 $\pm 6,76 \mathrm{~cm}$, ağırlık ortalamas1 $74,74 \pm 12,33 \mathrm{~kg}$, BKE ortalama değeri $26,24 \mathrm{~kg} / \mathrm{m}^{26}$ dir. Kadın bireylerin boy uzunluk ortalamas1 155,03 $\pm 5,93 \mathrm{~cm}$, ağırlık ortalamas $67,12 \pm$ $14,17 \mathrm{~kg}$, BKE ortalama değeri ise $28,02 \mathrm{~kg} / \mathrm{m}^{2}$ olarak bulunmuştur. Yaptığımız çalışma ile karşılaştırıldığında erkek bireylerin boy uzunluk değerlerinin benzer olduğu ancak ağırlık ortalamasının düşük olduğu görülmektedir. Kadın bireylerin değerlerine bakıldığında boy uzunluk ortalamasının daha yüksek olduğu ancak ağırlık ortalamasının düşük olduğu görülmektedir. Gültekin ve ekibinin (2009) yapmış olduğu çalışmada yaş grupları göz önüne alındığında ölçüm değerlerindeki farklılıkların olması oldukça doğaldır.

Erçim ve Pekcan (2014) Bingöl ilinde 19-35 yaş arasında olan bireyler üzerinde yaptıkları çalışma incelendiğinde erkeklerin boy uzunluk ortalaması 174,4 $\mathrm{kg}$, ağırlık ortalaması ise $70,3 \mathrm{~kg}$ olarak tespit edilmiştir. Yapmış olduğumuz çalışmada erkek bireylerin boy ve ağırlık ortalamasının sırasıyla yaklaşı $5 \mathrm{~cm}$ ve $6 \mathrm{~kg}$ daha düşük olduğu görülmektedir.

Yapılan çalışmalar göstermiştir ki bireylerin eğitim durumları, sahip oldukları çocuk sayısı ve bireylerin meslek grupları ile vücut bileşimi arasındaki ilişkiye bakıldığında, eğitim düzeyi düşük olan bireylerin Beden Kütle Endeksi'nin daha fazla olduğu sonucu ortaya çıkmaktadır (Gültekin, 2004). Bu durum göstermektedir ki şişmanlık, toplumsal eşitsizliklerden de kaynaklanabilmektedir. Yine yapilan farklı çalışmalarda, şişmanlığın sosyal tabakalar arasında farklılık gösterdiğini ortaya koymaktadır (Stunkard ve Sorensen, 1993). Çalışmamızda bireylerin eğitim durumu ile ağırlık ve BKE değerleri arasında bir ilişkinin olduğu görülmektedir $(p<0,05)$.

Gültekin ve ekibinin (2009) yapmış oldukları çalışmada benzer şekilde kadınların eğitim düzeyi ve erkeklerin meslek durumunun BKE üzerinde etkili olduğunu belirtmişlerdir. Delibasi ve ekibinin (2007) Türkiye'de yetişkin bireyler üzerinde yapmış olduğu çalışmada eğitim seviyesindeki düşüş ile birlikte BKE değerinin arttığını kaydetmiştir.

Bireylerin eğitim durumları ve aile içi birey sayısı sosyoekonomik yapılarının anlaşılabilmesi bakımından oldukça önemlidir. Örneklem grubuna bakıldığında erkek bireylerin $\% 72,8$ gibi büyük bir kısmının ortaokul mezunu olduğu görülmektedir. Kadın bireylere bakıldığında ise yine durum benzer şekilde olup \%69,2'si ortaokul mezunudur. Hanedeki birey sayısının artması ile sosyoekonomik düzey arasında ters bir orantının olduğu bilinmektedir (Gültekin, 2004). Çalışma kapsamında bireylerin aile içi birey sayılarına bakıldığında 2 bireyden 18 bireye kadar büyük bir dağılım göstermektedir. En fazla oran ise \%19,5 ile 6 kişilik aile, \%14,2 ile 5 kişilik aile, \%12,6 ile 7 kişilik aile, \%11,9 ile 8 kişilik aileler olușturmaktadır.

Bireylerin çalıştıkları yıl miktarı incelendiğinde bu bireylerin küçük yaşlardan beri çalışmaya başladıkları sonucu ortaya çıkmaktadır. Çalışmaya başlama yaşı, fiziksel ve ruhsal gelişimi etkileyen faktörlerin başında gelmektedir. Çalışmaya başlama yaşı düştükçe bireylerin bu dönemlerde fiziksel ve ruhsal gelişim açısından etkilenecekleri bir gerçektir (Duyar ve Özener, 2003).

Bekar (2011) yapmış olduğu çalışmada mesleki eğitim merkezinde kalfalık eğitimi gören bireylerin alkol kullanım oranlarını \%13,2 olarak tespit etmisstir. Alkol tüketen bireylerin \%95,5'ini erkekler oluşturmaktadır. Yapmış olduğumuz çalışma sonuçları incelendiğinde bireylerin alkol tüketim sıklığ1 erkek bireylerde \%10,0, kadın bireylerde ise \%0,9 olarak tespit edilmiştir. Grup geneline bakıldığında ise toplamda \% 7,1 oranında alkol tüketilmektedir. Bireylerin alkol kullanım oranlarının oldukça düşük olduğu görülmektedir. $\mathrm{Bu}$ durum bireylerin sağlığını koruması, iyileştirmesi ve hastalıkların önlenmesi açsından oldukça güzel bir bulgudur. Sigara kullanım oranlarına bakıldığında ise bireylerin \%41,3’ü sigara kullanmaktadır. Bu durum işçilere sağlık ve ekonomik yönden büyük bir ek yük getirmektedir. Türkiye'de 5727 Sayl1 yasa ise 19 Temmuz 2009 tarihinden itibaren evler hariç her türlü kapalı ortamda sigara tüketimi yasaklanmış olmasına rağmen kadın ve erkek bireylerde sigara kullanımının azalmamış olması oldukça ilginçtir.

Bireylerin beslenme alışkanlıkları da oldukça önemlidir. Gün içerisinde sabah, öğle ve akşam ögünlerini atlamadan yemek yemenin, bireyin sağllğı ve iş güvenliği açısı bakımından oldukça önemli olduğu bilinmektedir (Bilge, 2009).

Haklı (2008) çalışan bireyler üzerinde yapmış olduğu çalışmada \%44,0’ünün üç ana öğün ve bir ara öğün yemek yediğini tespit etmiştir. Ayrıca \%60,8’inin öğün atladığını, \%76,6'sının en çok sabah kahvaltısını, \%12,5'inin akşam yemeği, \%11,2'sinin ise öğle yemeğini atladığını tespit etmiştir. Bireylerin \%33,6'sının geç uyandığ1 için ögün atladığını \%64,4'ünün ise evde kahvaltı yaptığını belirlemiştir.

Bekar (2011) yapmış olduğu çalışmada bireylerin 
öğün sayıları ve atladıkları öğünler incelemiştir. Çalıșmaya göre 19-30 yaş grubu arasındaki bireylerin \% $\%$, 8 'i günde 1-2 öğün, \%70,6's1 3 öğün, \%20,6's1 ise 4 ve üzeri öğün tüketmektedir. Atlanılan öğünlere bakıldığında ise 19-30 yaş grubu bireylerin \%73,1'i sabah kahvaltıs1, \%19,2'si öğle yemeği ve \%7,7'si ise akşam yemeğini atladığ1 görülmektedir. Öğün atlayan bireylerin öğün atlama nedenlerine bakıldığında ise $\% 55,3$ 'ünün zaman bulamadığı, \%41,3'ünün can1 istemediği, \%5,7'sinin yemeği beğenmediği, \%2,4'ünün ise ekonomik nedenlerden dolayı öğün atladıklarını belirtmişlerdir (Bekar, 2011). Bir başka çalışmada bireylerin ögün atlama nedenlerine bakıldığında \%48'inin canının istemediği, \%32'sinin alışkanlığı olmaması, \%4'ünün geç kalkması gibi nedenler olduğu görülmektedir (Bilge, 2009).

Çalışmamızda bireylerin benzer sebeplerden dolayı ögün atladıkları ve benzer sonuçlara ulaşıldı̆̆1 görülmektedir. $\mathrm{Bu}$ durumun sebebi bireylerin ve ailelerinin beslenme konusunda bilinçsiz olmaları olabilir. Günlük öğün sayısını atlamamak, bireylerin sağlığının korunması ve geliştirilmesi için oldukça önemlidir.

Sağllğın korunması ve geliştirilmesi için beslenme durumunun özelikle toplumdaki duyarlı gruplarda (0-5 yaş grubu çocuklar, okul çağı çocuklar ve gençler, gebe ve emzikli kadınlar, doğurganlık çağındaki kadınlar, yaşlılar, issçiler) ve hasta olan bireylerde sürekli izlenmesi ve değerlendirilmesi gerekmektedir.

Toplumu olușturan bireylerin beslenme bilgi ve farkındalı̆̆ının oluşturulmasına yönelik politikaların oluşturulması, bireylerin sağlıklı bir şekilde hayatlarını devam ettirebilmeleri ve ileride oluşabilecek sağlık riskinin önüne geçilmesi büyük önem taşımaktadır.

\section{Teşekkür}

Makaleye katkılarından dolayı Doç. Dr. Okan Arıhan'a, çalışmaya yardımlarından dolayı Vali Alipaşa Meslekî Eğitim Merkezi okul müdürü Murat Yılmaz’a, ve rehber öğretmeni İshak Akyol'a, Aydın Göçeber ve Mehmet Akif Kocadeniz'e teșekkür ederiz.

\section{Kaynakça}

Baysal A. (2011). Beslenme, 13. baskı. Hatipoğlu Yayınları.

Bekar, A. (2011). Mesleki eğitim merkezinde kalfallk-ustalı eğitimine devam edenlerin beslenme durumlar ve calısma kosullarmm performanslarna etkisi [Yayımlanmamış doktora tezi]. Gazi Üniversitesi, Eğitim Bilimleri Enstitüsü, Ankara.

Bilge, E. (2009). Bir isletmede çalısanlarn beslenme durumlar ve enerji harcamalarmın değerlendirilmesi [Yayımlanmamış yüksek lisans tezi]. Trakya Üniversitesi, Sağlık Bilimleri Enstitüsü, Edirne.

Bilici, S. (2006). Farkh işkollarında çalışan yer altı maden iş̧ilerinin enerji harcamalar ve beslenme durumlarmın saptanması [Yayımlanmamış doktora tezi]. Hacettepe Üniversitesi, Sağlik Bilimleri Enstitüsü, Ankara.

Delibasi, T., Karaaslan, Y., Ustun, I., Koroglu, E., ve Hosgor, S.
(2007). National prevalence of underweight, overweight and obesity in Turkey: Cross sectional study of a representative adult population. Central European Journal of Medicine, 2(3), 294-303. https://doi.org/10.2478/s11536-007-0024-4

Duyar, İ., ve Özener, B. (2003). Cocuk isçiler. Carpık gelişen bedenler. Ütopya Yayınevi.

Dölekoğlu, C. Ö., ve Yurdakul, O. (2004). Adana ilinde hane halkının beslenme düzeyleri ve etkili faktörlerin logit analizi ile belirlenmesi. Akdeniz. Üniversitesi İktisadi ve İdari Bilimler Fakültesi Dergisi, 4(8), 62-86.

Erçim, R. E., ve Pekcan, G. (2014). Genç yetişkinlerin beslenme durumunun sağlıklı yeme indeksi - 2005 ile değerlendirilmesi. Beslenme ve Diyet Dergisi, 42(2), 91-98.

Gültekin, T. (2004). Ankara'da yasayan erişkin bireylerin vücut bileșimi değerleri [Yayımlanmamış doktora tezi]. Ankara Üniversitesi, Sosyal Bilimler Enstitüsü, Ankara.

Gültekin, T., Özer, B. K., Akın, G., Bektaş, Y., Sağır, M., ve Güleç, E. (2009). Prevalence of overweight and obesity in Turkish adults. Anthropologischer Anzeiger, 67(2), 205-212. https://doi. org/10.1127/0003-5548/2009/0022

Haklı, G. (2008). Konya merkezdeki gida üretim ve tüketim tesislerinde çalısan ișçilerin beslenme alıșkanllklar ve beslenme durumlarmin belirlenmesi [Yayımlanmamış yüksek lisans tezi]. Selçuk Üniversitesi Sosyal Bilimleri Enstitüsü, Konya.

Hamraa, K. A. (2013). Mobilya üretiminde çalıșan ișçilerin beslenme durumlarnm ve bazl antropometrik ölçülerinin saptanması [Yayımlanmamış yüksek lisans tezi]. Hacettepe Üniversitesi, Sağlık Bilimleri Enstitüsü, Ankara.

Kavas, A. (2003). Sağhlılı yaşam için doğru beslenme, 3. basım. Literatür Yayınc1lik.

Koca Özer, B., ve Gültekin, T. (2013). Assessment of nutritional status using anthropometric measurements in Turkish adults, Ankara Üniversitesi Dil ve Tarih-Cografya Fakültesi Dergisi, 53(2), 1-12. https://doi.org/10.1501/Dtcfder 0000001338

Newman, C. (2004). Neden bu kadar sismamı? National Geographic Türkiye, 82-97.

Pekcan, G. (2008). Beslenme durumunun saptanması. Diyet el kitabı. Hatipoğlu Yayınevi.

Rakıcıoğlu, N. (1999). İşçi beslenmesi. Ankara İli Beslenme Alıskeanliklar ve Mutfak. Kültürü, Sempozyum Bildirileri ve Katalog içinde (s. 159-166). VEKAM Koç Üniversitesi Vehbi Koç Ankara Araştırmaları Uygulama ve Araştırma Merkezi, 159166.

Soylu, M. (2006). Sağlıklı beslenme - Sağlıklı süt. I. Ulusal Sağhl̆ğ Gelistirme ve Sağhk Eğitimi Kongresi Özet Kitabı. MarmarisMuğla, 37.

Sürücüoğlu, M. S. (1999). Beslenme ve sağlımız. Standart Araștırma / Inceleme Dergisi, 38(448), 40-52.

Şanlıer, N. (2005). Gençlerde biyokimyasal bulgular, antropometrik ölçümler, vücut bileşimi, beslenme ve fiziksel aktivite durumlarının değerlendirilmesi. Gaẓi Eğitim Fakültesi Dergisi, 25(3), 47-73.

Tanner, J. M. (1990). Growth as a mirror of conditions in society. G. W. Lindgren (ed.) içinde, Growth as a mirror of conditions in society (s. 9-48). Stockholm: Institute of Education Press.

Wadsworth, E. J. K., Simpson, S. A., Moss, S. C., ve Smith, A. P. 
(2003). The Bristol stress and health study: Accidents, minor injuries and cognitive failures at work. Occupational Medicine, 53(6), 392-397. https://doi.org/10.1093/occmed/kqg088

Weiner, J. S., ve Lourie J. A. (ed.) (1969). Human biology: A guide to field methods. Blackwell Scientific.

World Health Organization (WHO) (1995). Physical status: the use and interpretation of anthropometry. (Technical Report Series No. 854.) World Health Organization, Geneva. http://whqlibdoc. who.int/trs/WHO TRS 854.pdf?ua=1

\section{(c) (1) $(8)$ \\ BY NC 2020. Telif hakları yazar(lar)a aittir}

Bu makale Creative Commons Atıf-GavriTicari 4.0 Uluslararası (CC BY-NC 4.0)

lisansının hüküm ve şartları altında yayımlanan açık erişimli bir makaledir. 